\title{
Basal Transcription Factor
}

National Cancer Institute

\section{Source}

National Cancer Institute. Basal Transcription Factor. NCI Thesaurus. Code C19851.

Basal Transcription Factors are prokaryotic and eukaryotic proteins that cooperate with DNA-dependent RNA polymerases to initiate, inhibit or terminate transcription. 